\title{
Determinants of Firm Performance: A Subjective Model
}

\author{
Murugesan Selvam ${ }^{1}$, Jayapal Gayathri ${ }^{2}$, Vinayagamoorthi Vasanth $^{3}$, Kasilingam Lingaraja $^{3} \&$ Sigo Marxiaoli $^{3}$ \\ ${ }^{1}$ Professor and Head, Department of Commerce and Financial Studies, Bharathidasan University, India. \\ ${ }^{2}$ Assistant Professor, Department of Commerce and Financial Studies, Bharathidasan University, India. \\ ${ }^{3} \mathrm{Ph}$.D Research Scholar, Department of Commerce and Financial Studies, Bharathidasan University, India. \\ Correspondence: Murugesan Selvam, Professor and Head, Department of Commerce and Financial Studies, \\ Bharathidasan University, India. Mobile: +91 94430 25112, E-Mail ID: drmselvam@yahoo.co.in
}

Received: May12, 2016

Accepted: May27, 2016

Available online: June 8, 2016

doi:10.11114/ijsss.v4i7.1662

URL: http://dx.doi.org/10.11114/ijsss.v4i7.1662

\begin{abstract}
The performance of firm is a relevant construct, in strategic management research, across the globe and frequently it is used as a dependent variable. In spite of its relevance, there is hardly any consensus about its definition, dimensionality and measurement, which limits advances in research. This review article suggests a comprehensive subjective measurement model for performance of firms, based on indicators and findings of earlier research studies. The final subjective model was developed with nine determinants/dimensions, namely, profitability performance, growth performance, market value performance of the firm, customer satisfaction, employee satisfaction, environmental audit performance, corporate governance performance and social performance. It is found that these nine dimensions or determinants cannot be used interchangeably since they represent different aspects of firm performance and different stakeholders of firms have different demands that need to be managed independently. Researchers and practitioners may use the proposed subjective model, in empirical studies, to evaluate the multiple performance of a firm.
\end{abstract}

Keywords: Strategic Management, Firm Performance, Measurement Model and Subjective Indicators.

\section{Introduction}

The strategic management is seen as a systematic process which aims at maximizing the utilization of resources in relation to organizational objectives which are in conformity with the demands of the business environment. The strategic management normally looks beyond the mere day-to-day operations of the business, as it is long term in nature. Hence it aims at creating a good future, without neglecting the present, thereby providing an appropriate platform for reacting to changes in business environment.

Strategic management is an applied field of business and as such, its survival and growth depend not only on its theoretical sophistication and the rigour of its methods but also on its relevance to practitioners. According to the findings of earlier studies, those firms, that are sophisticated users of strategic management, are more successful than firms that have not yet acquired strategy-making skills (Pekar, P. J., \& Abraham, S., 1995). The practitioners often do not perceive strategy-making as relevant to improving their firm performance (Heracleous, L., \&DeVoge, S., 1998). Besides, some researchers like Eden, C., \& Ackermann, F. (1998) proposed that the strategy-making process may be the most important factor that determines the ability of a firm to realise its strategic intention. Besides, the strategy-making process of firm may have a profound impact on the performance of a firm (Hart, S. L., and Banbury, C., 1994). Therefore, the performance of firm is a relevant construct in strategic management research.

The rigorous construct measurement is critical for the advancement of science, particularly when the variables of interest are complex or not observable. Paradoxically, the strategic management has been criticized for not giving the topic of firms' performance, high priority (Boyd, B.K., et al., 2005). However, the firm performance is one of the most relevant constructs in the field of strategic management (Rumelt, R. P., et al., 1994). A construct to measure firms' performance may have to be developed in such a way to be commonly used as the final dependent variable (Richard. P.J., et al., 2009). Despite its relevance, the research on the firm performance suffers from problems such as lack of consensus, selection of indicators based on convenience and little consideration of its dimensionality (Combs et al., 2005; Crook, T. R., et al., 2008; and Richard. P. J., et al., 2009). Many earlier studies measured the firm performance with a single indicator. (Glick, W. H., et al., 2005). Since several dimensions do exist, a researcher would have to 
choose all the dimensions most relevant to the relevant research and judge the outcomes of this choice (Richard. P.J., et al., 2009). The field of strategic management needs a clear conceptualization of firm performance and effective discussions about its dimensions and better measurement efforts. Against this background, this review article proposes multidimensional measurement subjective model for firm performance. This review paper also stresses the use of confirmation factor analysis to test the subjective model before application in future.

\subsection{Statement of the Research Problem}

The present day business environment is in the age of discontinuity in which the changes occur on a continuous and disruptive basis. This makes business firms difficult to predict the future performance of firm with accuracy. The changes may be minor or significant. However, the degree of changes is not what really matters but the abilities of an organization, to effectively cope with these uncertainties in the levels of performance, are the big challenge. This, therefore, becomes the entry point for the application of strategic management in every organization. Besides, the identification of the factors/dimensions in respect of firm performance is an underlying issue of this study. Besides, there is a wide gap, between academic researchers and practitioners, in respect of using model to measure the performance of the firm with high rate of accuracy. Richard. P.J., et al. (2009) rightly viewed that academic researchers may not be measuring the performance to which the managers of the firms are really managing. But the practitioners may use this understanding of performance dimensionality, to judge the broader impact of their decisions and actions. Besides, the practitioners too could use the measures to control a company's position in the competitive environment. Against this background, an attempt has been made in this study to suggest a comprehensive subjective model, covering all relevant determinants, to measure the performance of the firm with accuracy, after carefully reviewing earlier articles published in academic journals and knowledge and experiences of researchers.

\subsection{Importance of the Study}

The study on the identification of relevant determinants of firms' performance is required in the context of changed and competitive business environment. The results of this study may be useful for advanced researchers and practitioners, to use a comprehensive model, to get accurate results on the firms' performance. This study can be the base for developing the appropriate scales for each dimension by the other researchers who are interested in measuring firm performance across industries with subjective indicators (Boyd, B.K., et al., 2005). The dimensional structure of the model could also help the scholars to select relevant performance indicators for specific research problems that comprehensively cover the different dimensions of performance of the firms considered for the investigation. Besides, the model can contribute to bridge the gap between academia and management practitioners.

\subsection{Aim of the Study}

The aim of this review article is to suggest a comprehensive subjective model with a review to minimize the gap between academic and practitioners in respect of using model to measure the firm performance.

\section{Methods of Present Study}

The conceptual proposal on the performance of firms suggested by Venkatraman, N., \& Ramanujam, V. (1986) is widely used by Carton, R. B., \& Hofer, C. W., 2006 and Richard. P. J., et al., 2009. The analysis of operationalization of firm performance, made in different empirical earlier studies, vividly shows a wide variety of approaches covering this domain, in an unbalanced way. It is appropriate to refer here that Combs. J. G., et al., (2005) identified 238 empirical studies that used 56 different indicators, in respect of firms' performance. In most cases, the financial performance was used largely (82\%), with accounting measures of profitability, being the most common choice (52\%). Carton, R. B., \& Hofer, C. W. (2006) and Richard. P.J., et al., (2009) reported a similar picture, after analyzing different journals in other time periods. But there is a strong feeling among researchers that there has been no comprehensive subjective model, covering all the relevant aspects of firm performance, for evaluation with accuracy as required by business community in a competitive business environment.

Against this background, an attempt has been made in this study to suggest a comprehensive subjective model, after carefully reviewing the articles published in top academic and professional journals and subject knowledge of the researchers. To ensure a selection of indicators, to be consistent with the Indian business environment, the study examined the annual reports of leading companies in India. Besides, a particular variable was considered as relevant if the same variable was used for the analysis by other researchers and the results have not published in more than two articles in top journals. To identify the potential indicators for each presumed performance aspect (growth performance, profitability performance, market value performance, customers' satisfaction and employees' satisfaction, environmental performance, environmental audit performance, corporate governance performance and social performance), the present study reviewed earlier papers published in related academic journals. Based on this examination, this review paper identified performance indicators. 


\subsection{Feedback}

Corporate officials like managers and other top officials were contacted by the researchers. Their views and valuable information helped the researchers to identify the relevant determinants of firms' performance and develop the subjective model for the same.

\subsubsection{Limitations of the Study}

- This study was mainly based on review of earlier studies (relating to firms' performance), published in academic journals. Hence it could be riddled with certain limitations which are bound to be connected with the articles referred.

- The criticism applicable to review of literatures is applicable to this study also.

- This study, by its nature, is a review study. It did not apply any confirmatory test to validate the models.

- No comparison has been made on the identification of determinants of performance between small and large firms or other types of firms.

\subsection{Firm Performance Domain}

An attempt has been made in this study, to develop the model for firm performance, accurately based on the stakeholder theory (Freeman, R. E., 1984) and carefully select a list of indicators to fully represent the concept of firm performance. This review paper designed the measurement model, to allow comparison across firms, giving scope for testing it with a sample of senior managers and board members of companies and stake holders in India and abroad. These measures are preferable when the focus is on inter-firm comparison (Ketokivi, M. A., \& Schroeder, R. G., 2004). The assessment of non-financial criteria has also been allowed in the model (Richard et al., 2009). Their use is warranted since they have been proved to be positively associated with objective measures (Dawes, J., 1999; Forker, et al., 1996; Venkatraman, N., \& Ramanujam, V., 1987; Wall et al., 2004).

The concept of firm performance is different from the broader construct of organizational effectiveness. According to Venkatraman, N., \& Ramanujam, V. (1986), the broader construct covers three overlapping concentric circles, with the largest representing organizational effectiveness. The organizational effectiveness covers all aspects related to the functioning of the organization (Cameron, 1986a). Business performance or firm performance is a subset of organizational effectiveness that covers both operational and financial outcomes.

The operational performance, as described by Venkatraman, N., \& Ramanujam, V. (1986), could be best viewed as an antecedent to financial performance, mediating the effect of resources. While the customer satisfaction may be an antecedent to financial performance, is it not a performance outcome in itself as well? This depends on how a researcher defines firm performance for his/her studies (Combs. J. G., et al., 2005). It is significant that defining the performance, as the satisfaction of stakeholders (Connolly, et al., 1980; Hitt, 1988 and Zammuto, 1984), helps to differentiate between antecedents and performance outcomes. In this case, customer satisfaction is clearly an outcome (using the customer - a stakeholder - perspective) and thus become part of firm performance. Besides, in today's highly competitive environment, the organizations need to protect the long term interests of customers (Clement Sudhahar, J. et al., 2006).

\subsection{A Stakeholder Approach to Firm Performance}

The other factors are the profit and growth which are relevant justification for the existence of a business firm and they must be included in any attempt to measure performance of firms. A company may grow internally or externally. The most corporate growth occurs by internal expansion (Selvam, M. et al., 2010). The growth of the Indian corporate sector has been facilitated by stock exchanges (Gayathri, M and Selvam, M, 2014). The stakeholder theory (Freeman, R. E., 1984) helps the researchers to identify the parameters to measure the performance. Measuring the performance, under this conceptualization, involves identifying the stakeholders and defining the set of performance outcomes that measure their satisfaction (Connolly et al., 1980; Hitt, 1988 and Zammuto, 1984).

For business enterprise, 'profit' is the objective to grow and survive in the market (Selvam, M., 1991 and 1992). The social objective of public sector may be related to quality of service which attracts the customers/passengers (Selvam, M., 1989 and 1990). Service Quality is the function of perceptions, expectations and performance of firms (Clement Sudhar, J, and Selvam, M., 2007). The competitive service quality, in the cutthroat competition, is important for survival and existence of institutions (Isaiah, et al., 2015).

The stakeholder theory offers a social perspective to the objectives of the firm but it conflicts with the economic view of value maximization. The stakeholder theory is widely used in the corporate and academic world. It is possible to see its influence in corporate annual reports. The satisfaction of different stakeholders, being considered as a variable for the firm performance, was also adopted by a large number of researchers and authors like Agle, et al., 1999; Clarkson, 1995; 
Kaplan and Norton, 1992; Richard et al., 2009; Venkatraman, N., \& Ramanujam, V., 1986 and Waddock and Graves, 1997a. The use of this theory allows one to resolve the issue of differentiating between performance antecedents and outcomes. The performance measures assess the satisfaction of different groups of stakeholders. This conceptualization of firm performance is applicable across different companies, as remarked by Carneiro et al., (2007), allowing one to differentiate between high and low performers in the eyes of each stakeholder. Some researchers emphasized that the satisfaction as performance measure, should be assessed from all stakeholders' point of view.

Freeman, R. E. (1984) defines a stakeholder as "any group or individual who can affect or is affected by the achievement of the organization's objectives". This definition literally may include an unmanageable number of constituencies. Clarkson (1995) prescribed some important groups of stake holders of firms. It is to be noted that the views of shareholders and employees of firms, for example, should always be present in any analysis. Other primary stakeholders are suppliers and customers since they have a direct relationship with the firm. Secondary stakeholders have indirect relationships with the performance of firm but are clearly affected by its actions, mainly in terms of the social or environmental consequences. Donaldson and Preston (1995) listed out several classes of other stake holders which included governments, trade associations, communities and political groups and public. Each stakeholder has its own agenda in relation to the company and values a particular set of goals (Fitzgerald and Storbeck, 2003). It is significant to note that pleasing all parties equally, may be an unachievable task for the firms and therefore, managers need to prioritize. Mitchell et al., (1997) offered a method to identify and judge the salience of the stakeholders relevant to a firm.

\section{Multidimensional Models for Firm Performance}

A comprehensive construct (model), on firms performance, can be unidimensional or multidimensional. Figure-1 displays the list of identified determinants, i.e., possible representations of firm performance. It is to be noted that the identified determinants for firm performance are profitability performance, growth performance, market value performance, customers' satisfaction, employees' satisfaction, environmental performance, environmental audit performance, corporate governance performance and social performance. As pointed out earlier, these determinants were identified, based on the reviews published earlier.

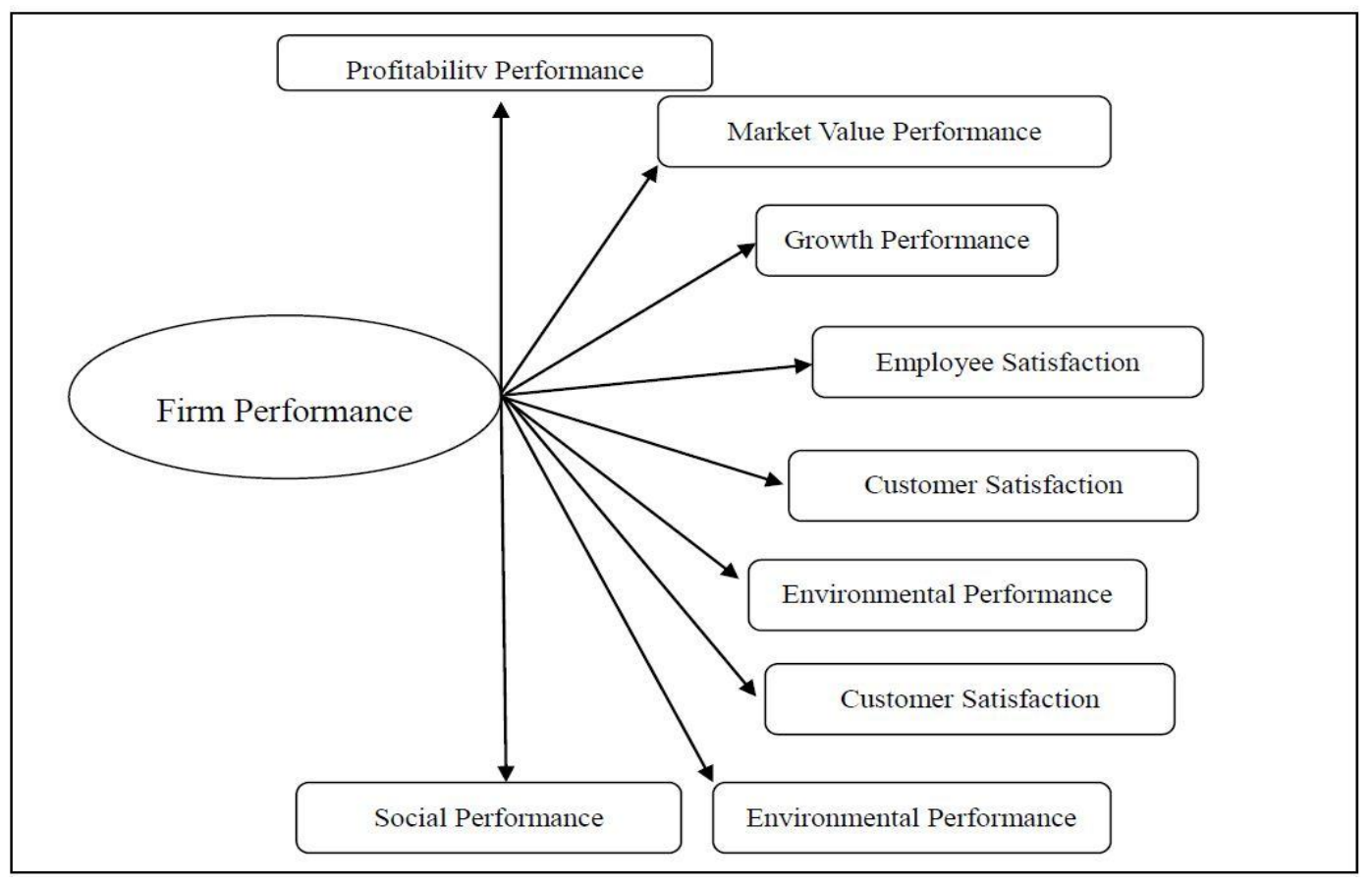

Figure 1. List of identified Determinants for Firm Performance

Source: Developed from various related studies including M. Selvam (2016).

Profitability performance is the ability of a business to earn a profit. A profit is what is left of the revenue a business generates, after it pays all expenses, directly related to the generation of the revenue, such as producing a product, and other expenses related to the conduct of the business activities. The objective of the firm is to maximize wealth of the existing shareholders (Vanitha, S. and Selvam, M., 2012). Superior financial performance is a way to satisfy investors (Chakravarthy, 1986) and it can be represented by profitability, growth and market value (Cho and Pucik, 2005 and 
Venkatraman, N., \& Ramanujam, V., 1986). These three aspects like profitability, growth and market value, complement to each other. The profitability measures a firm's past ability to generate returns (Glick, W. H., et al., 2005). Market value performance refers to the price in the market. The financial asset, like the share of a company, should fetch value in the marketplace. Market value is also commonly used to refer to the market capitalization of a publicly-traded company and it is obtained by multiplying the number of its outstanding shares by the current share price.

Market Value is considered as a possible variable and it represents the external assessment and expectation of future performance of firms. It should have a correlation with historical profitability and growth levels of firms but also incorporate future expectations of market changes and competitive moves. The diversification strategy provides effective risk minimization and return maximization (Lingaraja, K., et al., 2015). The market value of a firm is thus a key concern and it is the ability to predict stock trends, based on publicly disclosed information. Information relevant to stock returns is important for both general investors and stakeholders of publicly listed corporations. Market anomalies help the investors to gain from market movements. Maximization of stakeholder and investors value via the better performance of business operation is revealed on the stock market by the indices of financial report and other required information on the stock market (Tsung-UuanTsay and Yeong-Jia Goo, 2006). The studies on weak form efficiency and semi-strong form efficiency reveal the share price performance. Growth performance of the firm refers to a positive change in size, and/or maturation, often over a period of time. Growth normally occurs as a stage of maturation or a process toward fullness or fulfillment.

The growth demonstrates a firm's past ability to increase its size (Whetten, 1987). The growth in the size, even at the same profitability level, will increase its absolute amount of profit and cash generation. Larger size of firms also may bring economies of scale and market power, leading to enhanced future profitability of firms. Rajesh Ramkumar et al., (2015) pointed out that the development of financial markets has significant impact on economic growth. The stock indices, apart from being an indicator of the market movements, serve as a benchmark for measuring the performance of stocks under that index (Selvam et al., 2012). Employee Satisfaction refers to employees' satisfaction with their roles and responsibilities, the work environment, and their experiences with management. It is necessary to find out what mix of benefits matters most to them, and what skills they wish to acquire as they develop their careers.

The satisfaction of employees is directly related to investments in human resources practices. The employees are the group which tends to enhance firms' value and hence there are clearly defined job descriptions, investment in training, career plans and good bonus policies (Harter et al., 2002). The satisfaction of employees, according to Chakravarthy (1986), translates itself into a firm's ability to attract and retain employees and record lower turnover rates in the long run. Customer Satisfaction is a measure of how products and services, supplied by a company, meet or surpass customer expectation. It is seen as a key performance indicator within business. Customer satisfaction provides a leading indicator of consumer purchase intentions and loyalty.

Selvam, M. (1992) stressed that the service efficiency (Customer Satisfaction) of corporates need to be evaluated from the view point of passengers (Customer), operators, bus crew / managers, government, public or personal observation. Customer and employee satisfaction are two further aspects to be considered in all contexts. Customers want companies to provide them with goods and services that match their expectations (Fornell et al., 1996). The customer is the focus point to improve the business (Selvam, M., 2005). The companies must understand the needs of a customer avoid defects and improve the perceived quality of the services, in a competitive era and add value to their offerings. Customer satisfaction increases the willingness-to-pay and in the process, the value is created by a company (Barney and Clark, 2007). Environmental performance indicator is an analytical tool, to compare various plants in a firm or various firms in an industry, with respect to certain environmental characteristics.

Indirect stakeholders, like governments and communities (public), are affected by a number of firms' actions, especially social and environmental ones. Social and environmental performance can be considered as the way to satisfy communities (Chakravarthy, 1986) and governments (Waddock and Graves 1997a). All over the world, deterioration of environmental quality has been considered as a hot issue. The growing number of industries is one of the major reasons for the enhanced level of pollution and fast degradation of environmental resources (Vasanth, V. et al., 2015 ). The organizational structures need to be changed to suit the customers' need. The select activities, associated with the satisfaction of these stake holder groups, include safe environmental practices, enhanced product quality and safety, ethical advertisement, employment to minority and development of social projects (Agleet al., 1999; Johnson and Greening, 1999 and Waddock and Graves, 1997 , Waddock and Graves, 1997 ). Therefore, the conceptualization of firm performance is based on satisfying these STAKEHOLDERS. Environment-related information would certainly help to take both internal and external decision making of the firms (Vasanth, V. et al., 2012). According to Vasanth, V. et al $\left(2015_{\mathrm{a}}\right)$, it is essential that when the company earns more profit from the operation of the business, it should spend a portion of amount towards environmental protection. Environmental audit is one among the comprehensive approaches to an environmental management system of a firm because it helps to reduce the impact of their activities on the 
environment. Social performance is defined as "the effective translation of an institution's mission into practice in line with accepted social values." In other words, social performance is about making an organization's social mission a reality. In order to achieve strong social performance, an organization must manage its social performance as carefully and deliberately as it manages its financial performance.

Shleifer and Vishny (1997) define Corporate Governance as "the ways in which, suppliers to finance to corporations, assure themselves of getting a return on their investment". Yermack (1996) indicated that smaller boards could lead to higher market values. The World Bank in 1999 stated that corporate governance comprises two mechanisms, internal and external corporate governance. Internal corporate governance, giving priority to shareholder's interest, operates on the board of directors to monitor top management. On the other hand, external corporate governance monitors and controls manager's behavior, by means of external regulations and force, in which many parties are involved, such as suppliers, debtors, accountants, lawyers, providers of credit ratings and investment bank.

Research on Corporate Social Performance has provided a variety of perspectives on the social role and responsibilities of business. Friedman (1970) contended that the social responsibility of business is to make profit. Like many neoclassical economists, he separates business from society and declares the concepts of social responsibility as a fundamentally subversive doctrine. An extended concept of corporate social performance describes the contribution of business to society. Roman et. al., (1999), in their exploration of studies of the corporate social and financial performance relationship, indicated the dominance of positive relationships. According to Akerlof (1970), profitable firms are more likely to disclose more social and environmental information than companies with lower level profitability.

The grouping of determinants (Dimensions), for firm performance, is given in Figure-2. It is clear that all the nine factors are grouped into two: Financial Performance and Strategic Performance. The financial performance covers three variables, namely, profitability performance, growth performance and market value performance while strategic performance includes six other variables such as employee satisfaction, customers' satisfaction, environmental performance, environmental audit performance, corporate governance performance and social performance. Besides, each dimension symbolizes one facet of the overall result of the company, and it is represented by a particular group of indicators.

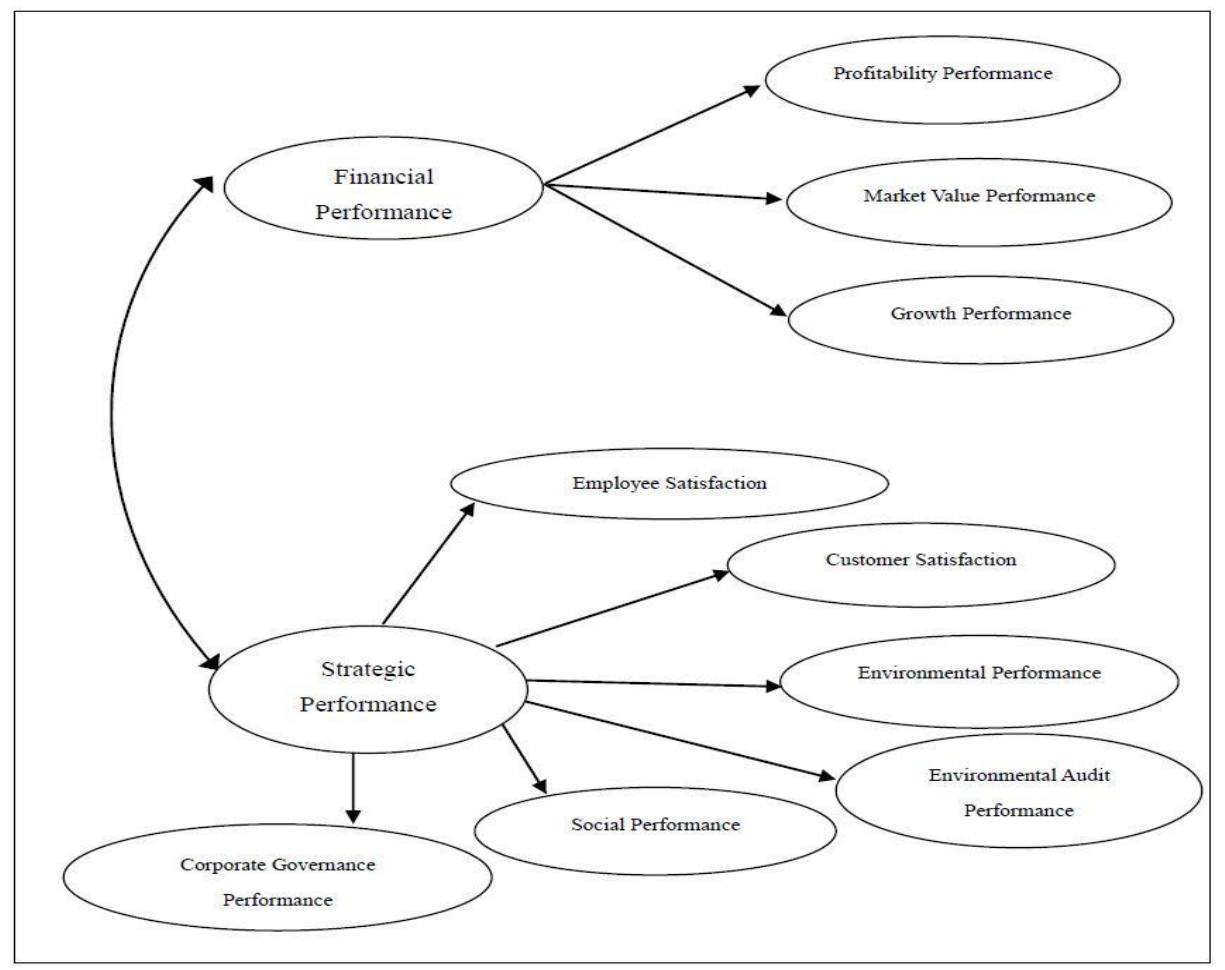

Figure 2. Grouping of Determinants for Firm Performance

Source: Developed from various related studies including M. Selvam (2016).

Table-1 brings out the nine dimensions and list of indicators for each dimension for firm performance. The list of indicators, for all the nine dimensions, is given in the Table. A total of 46 indicators identified, reveals firms' performance, from different perception. This number can further be extended considering other relevant dimensions of firm performance. 
Table 1. Dimensions and Sample Indicators for Firm Performance

\begin{tabular}{|c|c|c|c|}
\hline Sl. No. & Dimensions & Sample Indicators & No \\
\hline 1 & Profitability Performance & $\begin{array}{l}\text { Return on Assets, EBTIDA Margin, Return on Investment, Net } \\
\text { Income/Revenues, Return on Equity, Economic Value Added (EVA) }\end{array}$ & 6 \\
\hline 2 & Market Value Performance & $\begin{array}{l}\text { Earnings Per Share, Changes in Stock Price, Dividend Yield, Stock } \\
\text { Price Volatility, Market Value Added (Market Value / Equity), Tobin's } \\
\text { Q (Market Value / Replacement Value of Assets) }\end{array}$ & 6 \\
\hline 3 & Growth Performance & $\begin{array}{l}\text { Market-Share Growth, Asset Growth, Net Revenue Growth, Net } \\
\text { Income Growth, Number of Employees Growth }\end{array}$ & 5 \\
\hline 4 & Employee Satisfaction & $\begin{array}{l}\text { Turn-over, Investments in Employees Development and Training, } \\
\text { Wages and Rewards Policies, Career Plans, Organizational Climate, } \\
\text { General Employees' Satisfaction }\end{array}$ & 6 \\
\hline 5 & Customer Satisfaction & $\begin{array}{l}\text { Mix of Products and Services, Number of Complaints, Repurchase } \\
\text { Rate, New Customer Retention, General Customers' Satisfaction, } \\
\text { Number of New Products/Services Launched }\end{array}$ & 6 \\
\hline 6 & $\begin{array}{l}\text { Environmental } \\
\text { Performance }\end{array}$ & $\begin{array}{l}\text { Number of Projects to Improve / Recover the Environment, Level of } \\
\text { Energy Intensity, Use of Recyclable Materials, Recycling Level and } \\
\text { Reuse of Residuals, Volume of Energy Consumption, Number of } \\
\text { Environmental Lawsuits }\end{array}$ & 6 \\
\hline 7 & $\begin{array}{l}\text { Environmental Audit } \\
\text { Performance }\end{array}$ & $\begin{array}{l}\text { Environmental Policy, Environmental Audit Report } \\
\text { and Environmental Review }\end{array}$ & 3 \\
\hline 8 & $\begin{array}{l}\text { Corporate Governance } \\
\text { Performance }\end{array}$ & Board Size, Board Independence, Outside Directors, Insider Ownership & 4 \\
\hline 9 & Social Performance & $\begin{array}{l}\text { Employment of Minorities, Number of Social and Cultural Projects, } \\
\text { Number of Lawsuits Filed by Employees, Customers and Regulatory } \\
\text { Agencies }\end{array}$ & 4 \\
\hline & & Total & 46 \\
\hline
\end{tabular}

Source: Developed from various studies including Santos, J.B. \& Brito, L.A.L. (2012)

As pointed earlier, the purpose of this study is to minimize the gap in the model, used by the academicians and practitioners, to evaluate the performance of firms, with accuracy. Table -2 reveals the list of ratios to be used, for each dimension, under firm performance. The ratios were developed, based on the indicators identified, for each dimension. The other relevant dimensions could be added, and hence the list of ratios may be extended further.

Table 2. List of Ratios/ Parameters for each Dimension for Firms' Performance

\begin{tabular}{|c|c|c|c|}
\hline Sl. No. & Dimensions & Numbers & Ratios/ Parameters \\
\hline 1 & Profitability Performance & 6 & $\begin{array}{l}\text { ROA } \\
\text { EBTIDA Margin } \\
\text { ROI } \\
\text { Net Income / Revenue } \\
\text { ROE } \\
\text { EVA }\end{array}$ \\
\hline 2 & Market Value Performance & 6 & $\begin{array}{l}\text { EPS } \\
\text { Changes in Stock Price } \\
\text { Dividend Yield } \\
\text { Stock Price Volatility } \\
\text { Market Value Added } \\
\text { Tobin's Q }\end{array}$ \\
\hline 3 & Growth Performance & 5 & $\begin{array}{l}\text { Market Share Growth } \\
\text { Asset Growth } \\
\text { Net Revenue Growth } \\
\text { Net Income Growth } \\
\text { Number of Employees Growth }\end{array}$ \\
\hline
\end{tabular}




\begin{tabular}{|c|c|c|c|}
\hline 4 & Employee Satisfaction & 6 & $\begin{array}{l}\text { Turn-over } \\
\text { Investment in Employees Development and } \\
\text { Training } \\
\text { Wages and Rewards Policies } \\
\text { Career Plans } \\
\text { Organizational Climate } \\
\text { General Employees'Satisfaction }\end{array}$ \\
\hline 5 & Customer Satisfaction & 6 & $\begin{array}{l}\text { Mix of Products and Services } \\
\text { Number of Complaints } \\
\text { Repurchase Rate } \\
\text { New Customer Retention } \\
\text { General Customers' Satisfaction } \\
\text { Number of New } \\
\text { Products/Services Launched }\end{array}$ \\
\hline 6 & Environmental Performance & 6 & $\begin{array}{l}\text { Number of Projects to Improve / Recover the } \\
\text { Environment } \\
\text { Level of Energy Intensity } \\
\text { Use of Recyclable Materials } \\
\text { Recycling Level and Reuse of Residuals } \\
\text { Volume of Energy Consumption } \\
\text { Number of Environmental Lawsuits }\end{array}$ \\
\hline 7 & Environmental Audit Performance & 3 & $\begin{array}{l}\text { Environmental Policy } \\
\text { Environmental Audit Report } \\
\text { Environmental Review }\end{array}$ \\
\hline 8 & Corporate Governance Performance & 4 & $\begin{array}{l}\text { Board Size } \\
\text { Board Independence } \\
\text { Outside Directors } \\
\text { Insider Ownership } \\
\end{array}$ \\
\hline 9 & Social Performance & 4 & $\begin{array}{l}\text { Employment of Minorities } \\
\text { Number of Social and Cultural Projects } \\
\text { Number of Lawsuits Filed by Employees } \\
\text { Customers and Regulatory Agencies }\end{array}$ \\
\hline
\end{tabular}

Source: Developed from various studies including Santos, J.B. \& Brito, L.A.L. (2012)

\section{Conclusions and Scope for Further Research}

The firms' performance is relevant to the strategic management but it suffers from limited conceptualization, selection of indicators based only on convenience, and no proper consideration of its dimensionality. This review paper makes a contribution towards defining performance-related measurements. It is true that a comprehensive set of performance data is not available but these subjective measures can throw more light on limited objective data (Ketokivi, M. A., \& Schroeder, R. G., 2004). The selection of dimensions should carefully evaluate the most likely affective dimensions, as suggested by Ray et al., (2004). The appropriate scale is to be developed for the subjective model future expansion and use and for refining the model periodically, with additional dimensions and indicators suitable to the firms for time to time.

The model, suggested in this paper, clearly identified at least nine dimensions: profitability performance, market value performance, growth performance, employee satisfaction, customer satisfaction, environmental performance, environmental audit performance, corporate governance performance and social performance. Multidimensionality implies indicators of different dimensions cannot be used interchangeably since they represent different aspects of firm performance. The strategies may also have different impacts on each dimension.

This type of research certainly has some inherent limitations that could be explored in the future. Besides, the stakeholders, who were considered to delimit the scope of the measurement model, were the ones commonly mentioned by companies of one country, limiting the model to that country. The dimension, appropriate to different constituencies' satisfaction, was included for identifying the views of high-level executives of firms. They have access to objective data on firms' performance and they are in a position to make a balanced judgment regarding the different demands of each stakeholder group. However, the executives certainly do not fully represent all stakeholders. Another limitation of this study is linked to reliability. Finally, market value of the firm was also tested as a possible dimension since the market value is conceptually linked to firms' financial performance (Combs. J. G., et al., 2005).

The present study creates a platform, for further research, in respect of the followings: 
- The model, developed in the present review study, can be extended to any country with appropriate changes.

- Similar study could be conducted, by extending coverage of Journal / Papers / Research Studies, at different study periods.

- A comparative study could be made on the determinants of firms' performance.

- The confirmation factor analysis may be used to test the fitness of the Subjective Model.

- Periodical research/review could be made to identify the appropriate indicators for each dimensions of firm performance to keep face with the changing business environment.

\section{References}

Agle, B. R., Mitchell, R. K., \& Sonnenfeld, J. A. (1999). Who Matter To CEOs? An Investigation of Stakeholder Attributes and Salience Corporate Performance, and CEO Values. Academy of Management Journal, 42(5), 507-525. http://dx.doi.org/10.2307/256973

Barney, J., \& Clark, D. N. (2007). Resource-Based Theory. New York: Oxford.

Boyd, B. K., Gove, S., \& Hitt, M. A. (2005). Construct Measurement In Strategic Management Research: Illusion or Reality? Strategic Management Journal, 26(3), 239-257. http://dx.doi.org/10.1002/smj.444

Cameron, K. (1986). A Study of Organizational Effectiveness and its Predictors. Management Science, 32(1), 87-112. http://dx.doi.org/10.1287/mnsc.32.1.87

Carneiro, J. M. T., Silva, J. F., Rocha, A., \& Dib, L. A. R. (2007). Building a Better Measure of Business Performance. RAC-Eletrônica, 1(2), 114-135.

Carton, R. B., \& Hofer, C. W. (2006). Measuring Organizational Performance: Metrics for Entrepreneurship and Strategic Management Research. Cheltenham, UK, Northampton, MA:

Chakravarthy, B. S. (1986). Measuring Strategic Performance. Strategic Management Journal, 7(5), 437-458. http://dx.doi.org/10.1002/smj.4250070505

Cho, H., \& Pucik, V. (2005). Relationship between Innovativeness, Quality, Growth, Profitability, and Market Value. Strategic Management Journal, 26(6), 555-575. http://dx.doi.org/10.1002/smj.461

Clarkson, M. B. E. (1995). A Stakeholder Framework for Analyzing and Evaluating Corporate Social Performance. The Academy of Management Review, 20(1), 92-117. http://dx.doi.org/10.2307/258888

Clement, S. J., \& Selvam, M. (2007). Service Quality Scale Development in Indian Retail Banking Sector: An Empirical Investigation. Journal of Applied Sciences, 7(5), 766-771. http://dx.doi.org/10.3923/jas.2007.766.771

Clement, S., Duraipandian, I., Prabhu, B., \& Selvam, M. (2006). Service Loyalty Measurement Scale: A Reliability Assessment. American Journal of Applied Sciences, 3(4), 1814-1818. http://dx.doi.org/10.3844/ajassp.2006.1814.1818

Combs, J. G., Crook, T. R., \& Shook, C. L. (2005). The Dimension of Organizational Performance and its Implications for Strategic Management Research. Research Methodology in Strategy and Management, In Ketchen, D. J., \& Bergh (Eds.), D. D., 259-286.

Connolly, T., Conlon, E. J., \& Deutsch, S. J. (1980). Organizational Effectiveness: A Multiple Constituencies Approach. Academy of Management Review, 5(2), 211-217. http://dx.doi.org/10.2307/257430

Crook, T. R., Ketchen, D. J., Jr., Combs, J. G., \& Todd, S. J. (2008). Strategic Resources and Performance: A Meta-Analysis. Strategic Management Journal, 29(11), 1141-1154. http://dx.doi.org/10.1002/smj.703

Dawes, J. (1999). The Relationship between Subjective and Objective Company Performance Measures in Market Orientation Research: Further Empirical Evidence. Marketing Bulletin, 10(3), 65-75.

Donaldson, T., \& Preston, L. E. (1995). The Stakeholder Theory of the Corporation: Concepts, Evidence and Implications. Academy of Management Review, 20(1), 65-91. http://dx.doi.org/10.2307/258887

Eden, C., \& Ackermann, F. (1998). Making Strategy. Thousand Oaks, CA: Sage.

Fitzgerald, L., \& Storbeck, J. E. (2003). Pluralistic Views of Performance. Management Decision, 41(8), 741-750. http://dx.doi.org/10.1108/00251740310496251

Forker, L. B., Vickeky, S. K., \& Droge, C. L. M. (1996). The Contribution of Quality to Business Performance. International Journal of Operations and Production Management, 16(8), 44-62. http://dx.doi.org/10.1108/01443579610125778 
Fornell, C., Johnson, M. D., Anderson, E. W., Cha, J., \& Bryant, B. E. (1996). The Americ an Customer Satisfaction Index: Nature, Purpose and Findings. Journal of Marketing,60(4), 7-18.

Freeman, R. E. (1984). Strategic Management: A Stakeholders Approach. Boston: Pitman.

Gayathri, M., \& Murugesan, S. (2014). Stock Market Reaction during the Global Financial Crisis in India: Fractal Analysis. Asia Pacific Journal of Management Research and Innovation, 10(4), 403-412. http://dx.doi.org/10.1177/2319510X14553724

Glick, W. H., Washburn, N. T., \& Miller, C. C. (2005). The Myth of Firm Performance. Proceedings of the Annual Meeting of American Academy of Management. Honolulu Hawaii.

Hart, S. L., \& Banbury, C. (1994). How Strategy-Making Processes Can Make a Difference. Strategic Management Journal, 15(4), 251-269. http://dx.doi.org/10.1002/smj.4250150402

Harter, J. K., Schmidt, F. L., \& Hayes, T. (2002). Business-Unit-Level Relationship between Employee Satisfaction: A Meta-Analysis. Journal of Applied Psychology, 87(2), 268-279. http://dx.doi.org/10.1037//0021-9010.87.2.268

Heracleous, L., \& DeVoge, S. (1998). Bridging the Gap of Relevance: Strategic Management and Organisational Development, Long Range Planning, 31(5), 742-754.

Hitt, M. A. (1988). The Measuring of Organizational Effectiveness: Multiple Domains and Constituencies. Management International Review, 28(2), 28-40.

Isaiah, O. M., Selvam, M., Vinayagamoorthi, V., Kasilingam, L., \& Mariappan, R. (2015). Efficiency Measurement of Kenyan Commercial Banks. Mediterranean Journal of Social Sciences, 6(4), S2, 621-631. http://dx.doi.org/10.5901/mjss.2015.v6n4s2p621

Johnson, R. D. A., \& Greening, D. W. (1999). The Effects of Corporate Governance and Institutional Ownership Types on Corporate Social Performance. Academy of Management Journal, 42(5), 564-576. http://dx.doi.org/10.2307/256977

Kaplan, R. S., \& Norton, D. P. (1992). The Balanced Scorecard: Measures that Drive Performance. Harvard Business Review, 70(1), 71-79.

Ketokivi, M. A., \& Schroeder, R. G. (2004). Perceptual Measures of Performance: Fact or Fiction? Journal of Operations Management, 22(3), 247-264. http://dx.doi.org/10.1016/j.jom.2002.07.001

Lingaraja, K., Selvam, M., \& Vasanth, V (2015). Long Run Dynamic Linkages between Emerging Stock Markets in Asia and a Developed Stock Market (DJIA). Research Journal of Applied Sciences, 10(5), 203-2011. http://dx.doi.org/10.3923/rjasci.2015.203.211

Mgbame, C. O., \& Ilaboya, O. J. (2013). Environmental Accounting Audit Decision and Firm Performance: An Empirical Investigation. Journal of Modern Accounting and Auditing,9(4), 447-458

Mitchell, R. K., Agle, B. R., \& Wood, D. J. (1997). Toward A Theory of Stakeholder Identification and Salience: Defining the Principle of who and What Really Counts. Academy of Management Review, 22(4), 853-886. http://dx.doi.org/10.2307/259247

Pekar, P. J., \& Abraham, S. (1995). Is Strategic Management Living Up to Its Promise? Long Range Planning,28(5), 32-44. http://dx.doi.org/10.1016/0024-6301 (95)00036-I

Rajesh Ramkumar, R., Selvam, M., Raja, M., Lingaraja, K., \& Vasanth, V (2015). Efficiency of Sectoral Indices: A Comparative Study on BSE and NSE Ltd. International Business Management, 9(3), 258-266. http://dx.doi.org/10.3923/ibm.2015.258.266

Ray, G., Barney, J. B., \& Muhanna, W. A. (2004). Capabilities, Business Processes, and Competitive Advantage: Choosing the Dependent Variable in Empirical Tests of the Resource-Based View. Strategic Management Journal, 25(1), 23-37. http://dx.doi.org/10.1002/smj.366

Richard, P. J., Devinney, T. M., Yip, G. S., \& Johnson, G. (2009). Measuring Organizational Performance: Towards Methodological Best Practice. Journal of Management, 35(3), 718-804. http://dx.doi.org/10.1177/0149206308330560

Rumelt, R. P., Schendel, D. E., \& Teece, D. J. (1994). Fundamental Issues in Strategy. Boston: Harvard Business School Press.

Santos, J.B., \& Brito, L.A.L. (2012). Toward a Subjective Measurement Model for Firm Performance. Brazillian Administration Review, 9(6), 95-117.

Selvam, M. (1989 \& 1990). Social Objectives of Public Transport Undertakings. Journal of Annamali University. 
Part-A Humanity, 35 \& 36, 199-225.

Selvam, M. (1991 \& 1992). Social Responsibility Vs Commercial Objectives in State Transport Undertaking. Journal of Annamali University. Part-A Humanity, 37 \& 38, 43-47.

Selvam, M.(1992). Service Efficiency of Pallavan Transport Coporation Limited in Madras City. Department of Commerce. Annamalai University. (Ph.DDessertation - Unpublished)

Selvam, M. (2005). Customer Satisfaction of Banking Services: An Overview. SAJOSPS, 6(1), 85-90.

Selvam, M. (2016). Service Efficiency of Pallavan Transport Corporation Limited in Madras (Chennai) City. Lambert Academic Publishing, ISBN: 978-3-659-89572-2.

Selvam, M.,\&Vanitha, S. (2004). Corporate Environmental Accounting and Reporting Challenges. Journal of the Association of Economists of Tamilnadu, XVI(1), 112-116

Selvam, M., Indhumathi, G., \& Lydia, J. (2012). Impact on Stock Price by the Inclusion to and Exclusion from CNX Nifty Index. Global Business Review, 13(1), 39-50. http://dx.doi.org/10.1177/097215091101300103

Selvam, M., Vanitha, S., Gayathri, J. Bennet, E., \& Nageswari, P. (2010). The Determinants of shareholders' wealth of acquiring firms in India. Journal of Modern Accounting and Auditing, 6(1), 46-54.

Shleifer, A., \& Vishny, R. W. (1997). A Survey of Corporate Governance. The Journal of Finance, 52(2), $737-783$. http://dx.doi.org/10.1111/j.1540-6261.1997.tb04820.x

Tsung-Yuan, T., \& Yeong-Jia, G. (2006). The Relationship of Profitability and Growth with Stock Market Returns in the Electronics Industry. International Journal of Management, 23(4), 763 -774.

Vanitha, S., \& Selvam, M. (2012). The Effect of Mergers and Acquisitions on Share holders' wealth - An Empirical Analysis. International Journal of Research in Commerce, Economics \& Management, 2(2), 59 - 69.

Vasanth, V., Selvam, M., \& Lingaraja, K. (2015a). Impact of Firms' Profitability on Environmental Performance: Evidence from Companies in India. Mediterranean Journal of Social Sciences, 6(1), 109-119. http://dx.doi.org/10.5901/mjss.2015.v6n1p109

Vasanth, V., Selvam, M., Lingaraja, K., Isaiah Onsarigo, M.,\& Raja, M. (2015b). Testing Environmental Kuznets Curve Hypothesis at Firm Level in India. Journal of Sustainable Development, 8(8), 201-212. http://dx.doi.org/10.5539/jsd.v8n8p201

Venkatraman, N., \& Ramanujam, V. (1986). Measurement of Business Performance in Strategy Research: A Comparison of Approaches. Academy of Management Review, 1(4), 801-814. http://dx.doi.org/10.2307/258398.

Venkatraman, N., \& Ramanujam, V. (1987). Measurement of Business Economic Performance: An Examination of Method Convergent. Journal of Management, 13(1), 109-122. http://dx.doi.org/10.1177/014920638701300109

Vinayagamoorthi, V., Murugasen, S., Kasilingam, L., Venkatraman, K., \& Mahalingam, G. (2012). Environmental Management Accounting - A Decision Making Tools. International Journal of Management,3(3), 144 - 151.

Waddock, S. A., \& Graves, S. B. (1997a). Quality of Management and Quality of Stakeholder Relations. Business and Society, 36(3), 250-279. http://dx.doi.org/10.1177/000765039703600303

Waddock, S. A., \& Graves, S. B. (1997b). The Corporate Social Performance-Financial Performance Link. Strategic Management Journal, $\quad 18(4), \quad 303-319 . \quad \mathrm{http} / / / \mathrm{dx} . \mathrm{doi} .0 \mathrm{rg} / 10.1002 /(\mathrm{SICI}) 1097-$ 0266(199704)18:4<303::AID-SMJ869>3.0.CO;2-G

Wall, T. D., Michie, J., Patterson, M., Wood, S. J., Sheeran, M., Clegg, C. H., \& West, M. (2004). On The Validity of Subjective Measures of Company Performance. Personnel Psychology, 57(1), 95-118. http://dx.doi.org/10.1111/j.1744-6570.2004.tb02485.x

Whetten, D. A. (1987). Organizational Growth and Decline Process. Annual Review of Sociology, 13(1), $335-358$. http://dx.doi.org/10.1146/annurev.so.13.080187.002003

Yermack, D. (1996). Higher Market Valuation of Companies with a Small Board of Directors. Journal of Financial Economics, 40(2), 185-211.

Zammuto, R. F. (1984). A Comparison of Multiple Constituency Models of Organizational Effectiveness. Academy of Management Review, 9(4), 606-616. http://dx.doi.org/10.2307/258484

\section{$(\mathrm{cc}) \mathrm{BY}$}

This work is licensed under a Creative Commons Attribution 3.0 License. 